\title{
Determination of Metabolic Viability and Cell Mass Using a Tandem Resazurin/Sulforhodamine B Assay
}

Filomena S.G. Silva, ${ }^{1,4}$ Irina G. Starostina, ${ }^{2,4}$ Vilena V. Ivanova, ${ }^{2}$ Albert A. Rizvanov, ${ }^{2}$ Paulo J. Oliveira, ${ }^{1}$ and Susana P. Pereira ${ }^{3}$

${ }^{1}$ Center for Neuroscience and Cell Biology, University of Coimbra, Cantanhede, Portugal

${ }^{2}$ Kazan Federal University, Institute of Fundamental Medicine and Biology, Kazan, Russia

${ }^{3}$ Department of Life Sciences, School of Sciences and Technology, University of Coimbra, Coimbra, Portugal

${ }^{4}$ These authors should be considered co-first authors

The identification of rapid, reliable, and highly reproducible biological assays that can be standardized and routinely used in preclinical tests constitutes a promising approach to reducing drug discovery costs and time. This unit details a tandem, rapid, and reliable cell viability method for preliminary screening of chemical compounds. This assay measures metabolic activity and cell mass in the same cell sample using a dual resazurin/sulforhodamine B assay, eliminating the variation associated with cell seeding and excessive manipulations in assays that test different cell samples across plates. The procedure also reduces the amount of cells, test compound, and reagents required, as well as the time expended in conventional tests, thus resulting in a more confident prediction of toxic thresholds for the tested compounds. (C) 2016 by John Wiley \& Sons, Inc.

Keywords: high throughput - human skin fibroblasts $\bullet$ preclinical tests • toxicity evaluation

\section{How to cite this article:}

Silva, F.S.G., Starostina, I.G., Ivanova, V.V., Rizvanov, A.A., Oliveira, P.J., and Pereira, S.P. 2016. Determination of metabolic viability and cell mass using a tandem resazurin/sulforhodamine B assay. Curr. Protoc. Toxicol. 68:2.24.1-2.24.15. doi: $10.1002 /$ cptx.1

\section{INTRODUCTION}

The development of new therapeutic agents from synthesis through market entry is a costly and time-consuming process (Adams and Brantner, 2006; Taylor, 2015). Novel preclinical assays that help predict drug behavior in humans prior to clinical analysis offer promising approaches to reduce the cost and time spent on this process (Brodniewicz and Grynkiewicz, 2010).

In the last decade, several in vitro and in vivo model systems have been employed in preclinical tests. Human cell culture assays have often been used as screening tools in the initial stages of preclinical research, especially by providing mechanistic approaches to chemical-biological interactions (Allen et al., 2005). Different cell models, including fibroblasts (Voytik-Harbin et al., 1998; Lee et al., 2000), lymphocytes (Ahmed et al., 1994; de Fries and Mitsuhashi, 1995), hepatocytes (Spryszynska et al., 2015; Wang et al., 2015), and cardiomyoblasts (Sardao et al., 2009; Moreira et al., 2014), as well as different cancer cell lines (Serafim et al., 2008, 2011), have been used to predict toxicological and pharmacological effects of compounds of interest. Human fibroblast 
cultures have been widely used in preclinical tests due to the ease of harvesting them from a large number of patients and the simplicity of the cell-culture procedures. The abundant availability of fibroblast lines with known genetic defects in worldwide cell banks also allows easy application of these cells to study effects and mechanisms of specific conditions, e.g., neurological diseases (Connolly, 1998). In fact, it has been proposed that skin fibroblasts are a good predictive model to investigate neurological disorders, principally because they exhibit the same phenotypic alterations found in the central nervous systems of patients (Fairbanks et al., 2002; Garrido-Maraver et al., 2012; Ambrosi et al., 2014; Mocali et al., 2014; Nguyen, 2014; Yang et al., 2015). Human fibroblasts have also been used as models to study the influence of different therapeutic agents in reverting the epigenetic Parkinson's disease state (Valente et al., 2012).

Currently, there is a broad spectrum of different biological assays available to quantify cell proliferation and/or cytotoxicity (Bopp and Lettieri, 2008). The most common methods used include assays based on measuring cell membrane integrity by lactate dehydrogenase leakage or by inclusion/exclusion of dyes (crystal violet, trypan blue, and neutral red), and methods of cell counting or quantification of protein mass, which include quantification of protein concentration or the sulforhodamine B (SRB) assay, as well as tests based on the metabolic activity of viable cells by reduction of tetrazolium salts [3-(4,5dimethylthiazol-2-yl)-2,5-diphenyl tetrazolium bromide (MTT), 2,3-bis(2-methoxy4-nitro-5-sulfophenyl)-5-phenylamino-carbonyl)2 H-tetrazolium hydroxide (XTI'), 5(3-carboxymethoxyphenyl)-2-(4,5-dimethylthiazoly)-3-(4-sulfophenyl)tetrazolium, inner salt (MTS), and 4-[3-4-iodophenyl]-2-(4-nitrophenyl)-2 H-5-tetrazolio)-1,3-benzene disulfonate (WST-1)] or resazurin (Voytik-Harbin et al., 1998; Niles et al., 2008). However, these assays measure only one cellular parameter, making them restrictive and easily prone to artifacts. For this reason, the selection of proper cytotoxic assays is generally a highly complex process, which takes into account different factors such as the nature and duration of the assay, the detection mechanism required, and the structure of the chemical compound to be tested. Moreover, discrepancies between methods used by various research groups often complicate comparison of results between independent research studies. There is an increasing need for the development of simple, rapid, reliable, and highly reproducible cell viability assays, which may be standardized and routinely used in a great number of in vitro cellular systems. The protocol described here shows the development of a more rapid and reliable cell viability method to be used in preliminary screening of chemical compounds. This procedure measures metabolic activity and cell mass in tandem, for the same cell sample, using a dual resazurin/SRB assay, thereby eliminating the variation associated with different assays and changes in external conditions, e.g., $\mathrm{CO}_{2}$ levels, temperature, and medium composition, which can occur if resazurin and SRB assays are not performed in the same sample (e.g., multi-well plate). The procedure presented here is divided in three parts-cell culture conditions (Basic Protocol 1), determination of metabolic activity by resazurin reduction assay (Basic Protocol 2), and quantification of cell mass using the SRB assay (Basic Protocol 3).

BASIC PROTOCOL 1

SRB/Resazurin Assay for Cell Viability and Metabolism

2.24.2

\section{CELL CULTURE OF FIBROBLASTS}

This protocol describes the sub-culturing of BJ skin fibroblasts in an adherent monolayer culture. Other cell lines may also be used; however, the culture conditions must be optimized according to the specifications of each cell type.

\section{Materials}

BJ skin fibroblasts cell line (ATCC, cat. no CRL-2522)

Phosphate buffered saline (PBS; see recipe)

$0.05 \%$ trypsin-EDTA (Life Technologies, cat. no 25300-062)

Growth medium (see recipe) 
$100-\mathrm{cm}^{2}$ cell culture dishes

Cell incubator, at $37^{\circ} \mathrm{C}$ with $5 \% \mathrm{CO}_{2}$ atmosphere

Inverted microscope

15-ml disposable conical polypropylene centrifuge tubes (e.g., Corning Falcon)

Additional reagents and equipment for cell culture, including counting cells and determining number of viable cells by trypan blue exclusion (APPENDIX $3 B$;

Phelan, 2007)

NOTE: The PBS, trypsin-EDTA, and growth medium (complete DMEM) should be preheated to $37^{\circ} \mathrm{C}$ just before use.

NOTE: Repeat each experiment at least three times using cells from independent cultures.

1. Grow cells on $100-\mathrm{cm}^{2}$ cell culture dishes in growth medium in a $37^{\circ} \mathrm{C}, 5 \% \mathrm{CO}_{2}$ incubator until density reaches $70 \%$ to $80 \%$ confluence.

APPENDIX 3B (Phelan, 2007) includes protocols for cell culture.

2. Remove the medium and wash the cell monolayer once with PBS.

3. Add $5 \mathrm{ml}$ of $0.05 \%$ trypsin-EDTA and keep the plate in the incubator for 5 to $7 \mathrm{~min}$ at $37^{\circ} \mathrm{C}$ in order to harvest adherent cells. Add $5 \mathrm{ml}$ of complete DMEM medium (with FBS) to inhibit trypsin.

4. Transfer the cell suspension to a $15-\mathrm{ml}$ polypropylene conical centrifuge tube and centrifuge $5 \mathrm{~min}$ at $500 \times \mathrm{g}$, room temperature.

5. Discard the supernatant and resuspend the pellet in 1 or $2 \mathrm{ml}$ of growth medium.

6. Mix $10 \mu \mathrm{l}$ of cells suspension with $10 \mu \mathrm{l}$ of $0.4 \%$ trypan blue and count viable cells in a hemacytometer.

More detail on the trypan blue exclusion test for cell viability can be found in APPENDIX 3B (Phelan, 2007).

7. Seed the cells at five different densities $\left(0.25,0.5,1,2\right.$ and $4 \times 10^{4}$ cells $\left./ \mathrm{cm}^{2}\right)$ in 48-well plates, in growth medium at $500 \mu \mathrm{l}$ per well according to the diagram shown in Figure 2.24.1.

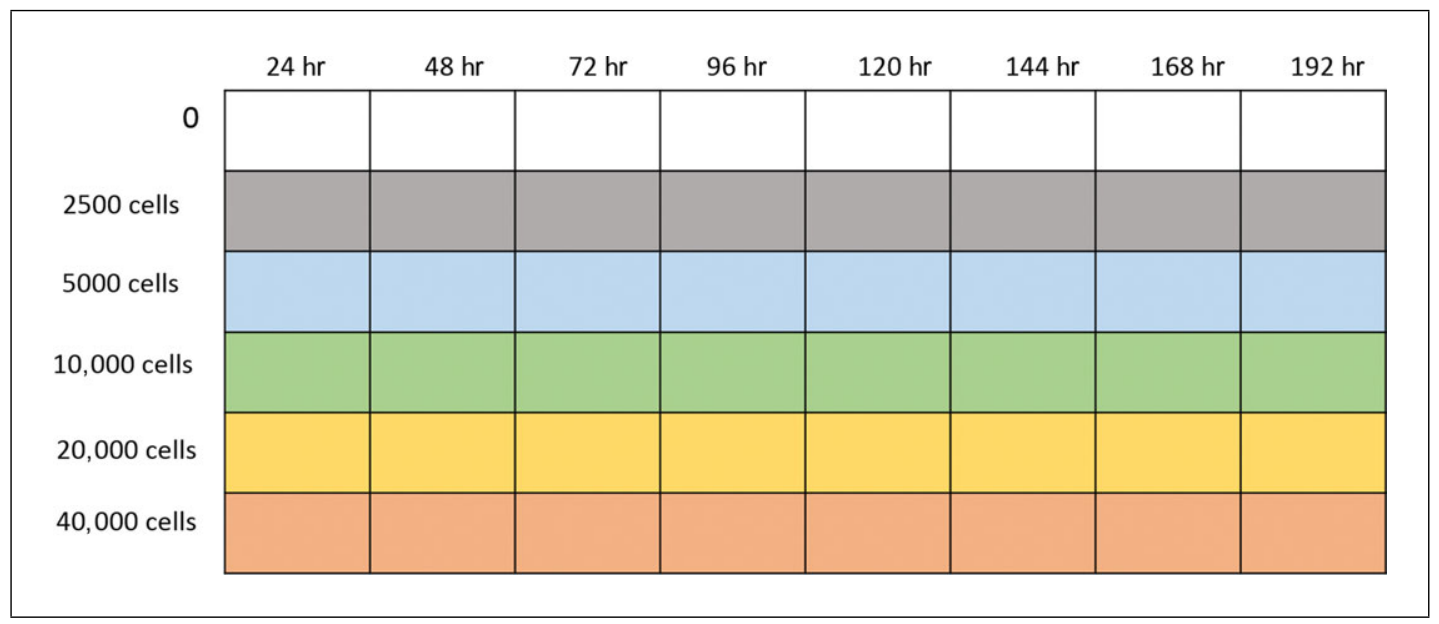

Figure 2.24.1 Recommended plate scheme for optimization of cell density and incubation time with resazurin and for the determination of cell viability and mass using a tandem resazurin/sulforhodamine $\mathrm{B}$ assay. White wells represent culture medium alone (internal control), gray wells contain $0.25 \times 10^{4}$ cells $/ \mathrm{cm}^{2}$, blue wells contain $0.5 \times 10^{4}$ cells $/ \mathrm{cm}^{2}$, green wells contain $1.0 \times 10^{4}$ cells $/ \mathrm{cm}^{2}$, yellow wells contain $2.0 \times 10^{4}$ cells $/ \mathrm{cm}^{2}$, and orange wells contain $4.0 \times 10^{4}$ cells $/ \mathrm{cm}^{2}$. 
Use each row to plate a different cell density (plate eight wells for each density); just add growth medium to the wells in the first row and use this row as an internal control.

8. Leave cells growing for $24,48,72,96,120,144,168$, and $192 \mathrm{hr}$, using a column for each time point (see Fig. 2.24.1 for plate map). At the end of each time point, proceed to Basic Protocol 2, where the resazurin solution will be added to the column corresponding to the respective time point of incubation. After fluorescence measurements, return the plate to the incubator until the next time point is measured.

9. Change the growth medium every 2 days until reaching $192 \mathrm{hr}$.

BASIC PROTOCOL 2

SRB/Resazurin Assay for Cell Viability and Metabolism

\section{RESAZURIN ASSAY FOR CELL VIABILITY ASSESSMENT}

The following protocol describes how to optimize the resazurin assay with different cell densities of BJ skin fibroblasts and different incubation times with resazurin, measuring the metabolic activity through the fluorescence intensity in a 48-well microplate reader format. Other cell lines may also be used, but the different cell densities and times of incubation with resazurin must be optimized.

\section{Materials}

Cells seeded in 48-well plates (see Basic Protocol 1)

Resazurin solution (see recipe)

Phosphate-buffered saline (PBS; see recipe)

Growth medium (see recipe)

Microplate reader

Computer running MS Excel and GraphPad Prism or SPSS (IBM)

1. For each cell growth time point $(24,48,72,96,120,144,168$, and $192 \mathrm{hr}$; see Basic Protocol 1, step 8), take the plate out of the cell incubator.

2. Remove the medium from each well in the column corresponding to the present time point and wash with PBS.

3. After removing the PBS wash, add $500 \mu 1$ of resazurin solution (freshly prepared each day from a 1:1000 dilution in growth medium from a stock solution) per well to the wells in the column corresponding to the specific treatment/culture time to be studied (see Fig. 2.24.1 for plate map).

Resazurin solution should be prepared under aseptic conditions and protected from light with aluminum foil.

The plate should also be covered with aluminum foil; change the foil daily to avoid the possibility of contamination.

4. Place the plate, covered with aluminum foil, in the incubator for $30 \mathrm{~min}$ at $37^{\circ} \mathrm{C}$ with a $5 \% \mathrm{CO}_{2}$ atmosphere.

5. Measure resorufin fluorescence (using excitation wavelength of $540 \mathrm{~nm}$ and emission of $590 \mathrm{~nm}$ ) using a microplate reader.

6. Repeat the measurements at 60,240 , and $360 \mathrm{~min}$.

7. At the last incubation time point (360 min), carefully remove the resazurin solution and medium.

8. Wash the corresponding column of adherent cells with $200 \mu 1$ of prewarmed $\left(37^{\circ} \mathrm{C}\right)$ PBS, carefully remove the PBS, and place the plate back in the incubator. 
9. Export data from the microplate reader in Excel format.

10. Represent the data with relative fluorescence units on the $y$ axis and time of incubation with resazurin or time of cell culture on the $x$ axis to determine the corresponding time-point for maximum viability, using software such as GraphPad Prism or SPSS.

\section{SULFORHODAMINE B COLORIMETRIC ASSAY}

The protocol outlines the procedure for the SRB assay, which is performed on the same set of skin BJ fibroblasts used to perform the resazurin assay. The SRB method will now measure cell mass ("protein") through determination of the absorbance of each sample in a 96-well microplate reader format. When using the SRB assay, cell protein is indirectly equivalent to total cell mass, which in turn correlates with cell number (Papazisis et al., 1997). Other cell lines may also be used, but the range of cell densities must be optimized based on the specificity of each cell type.

\section{Materials}

Cells seeded in 48-well plates, after performing resazurin assay for all time points (see Basic Protocol 2)

Phosphate-buffered saline (PBS)

$1 \%(\mathrm{v} / \mathrm{v})$ acetic acid in methanol (see recipe)

SRB solution (see recipe)

$1 \%(\mathrm{v} / \mathrm{v})$ acetic acid in MilliQ-purified $\mathrm{H}_{2} \mathrm{O}$

$10 \mathrm{mM}$ Tris- $\mathrm{NaOH}, \mathrm{pH} 10$ (see recipe)

96-well plates suitable for spectrometry

Orbital plate shaker

Microplate reader

Computer running MS Excel and GraphPad Prism or SPSS (IBM)

1. After performing the resazurin assay for each time point ( 24 to $192 \mathrm{hr}$ ), remove the culture medium from the wells in the column corresponding to the 192-hr time-point and wash cells once with PBS.

2. Add $500 \mu 1$ of $1 \%$ acetic acid in methanol to each well on the whole plate.

3. Cover the plate with aluminum foil and incubate at $-20^{\circ} \mathrm{C}$ at least $3 \mathrm{hr}$ or overnight, in order to promote cell fixation.

4. Discard the $1 \%$ acetic acid solution and dry the plate in an incubator at $37^{\circ} \mathrm{C}$ for $\sim 1$ $\mathrm{hr}$. The 48-well plate should be placed in the incubator with the lid open.

5. Add $250 \mu \mathrm{l}$ of SRB solution in each well and incubate for $1 \mathrm{hr}$ at $37^{\circ} \mathrm{C}$.

6. Discard the SRB solution and wash wells with $1 \%$ acetic acid prepared in MilliQpurified water.

7. Dry the plate in the incubator at $37^{\circ} \mathrm{C}$ for $1 \mathrm{hr}$ or overnight.

8. Add $250 \mu \mathrm{l}$ of $10 \mathrm{mM}$ Tris- $\mathrm{NaOH}, \mathrm{pH} 10$, and stir the plate for $30 \mathrm{~min}$ on an orbital plate shaker at room temperature.

9. Transfer $100 \mu \mathrm{l}$ from each well to a $96-$ well plate and read the absorbance at $510 \mathrm{~nm}$ and background measurement at $620 \mathrm{~nm}$, at room temperature.

\section{Data analysis}

10. Export data from microplate reader in Excel format.
BASIC

PROTOCOL 3
Assessment of Cell

Toxicity 
11. Represent the data with absorbance on the $y$ axis and time of cell culture on the $x$ axis, using software such as GraphPad Prism or SPSS.

\section{REAGENTS AND SOLUTIONS}

For the preparation of each solution, use ultrapure MilliQ-purified water to minimize contamination with metal ions as much as possible. For common stock solutions, see APPENDIX 2A.

\section{Acetic acid solution in methanol, $1 \%(v / v)$}

Add $5 \mathrm{ml}$ acetic acid to $495 \mathrm{ml}$ methanol, homogenize the solution, and store up to 1 year at $-20^{\circ} \mathrm{C}$.

\section{Acetic acid solution in MilliQ-purified water, $1 \%(v / v)$}

Mix $10 \mathrm{ml}$ acetic acid with $990 \mathrm{ml}$ MilliQ-purified water, and store at room temperature.

\section{Growth medium}

Dulbecco's modified Eagle medium (DMEM; Sigma, cat. no. D5030) supplemented with:

$25 \mathrm{mM}$ glucose

$4 \mathrm{mM}$ glutamine

$1 \mathrm{mM}$ sodium pyruvate

$21 \mathrm{mM}$ sodium bicarbonate

$10 \%$ fetal bovine serum (FBS; Invitrogen, cat. no. 16000-044)

$1 \times$ penicillin-streptomycin $[100 \mathrm{U} / \mathrm{ml}$ penicillin $/ 100 \mu \mathrm{g} / \mathrm{ml}$ streptomycin; add from $100 \times(10,000 \mathrm{U} / \mathrm{ml}$ penicillin $/ 10,000 \mu \mathrm{g} / \mathrm{ml}$ streptomycin; Invitrogen, cat. no. 15140-122)]

Dissolve $8.3 \mathrm{~g}$ of DMEM powder, $4.5 \mathrm{~g}$ of glucose, $0.584 \mathrm{~g}$ of glutamine, $0.11 \mathrm{~g}$ of sodium pyruvate, and $1.8 \mathrm{~g}$ sodium bicarbonate in $800 \mathrm{ml}$ MilliQ-purified water. Adjust to pH 7.2 to 7.4 using $\mathrm{HCl}$ or $\mathrm{NaOH}$ and bring the solution to $890 \mathrm{ml}$ with MilliQ-purified water. Supplement the solution with $100 \mathrm{ml} \mathrm{FBS}$ and $10 \mathrm{ml}$ of $100 \times$ penicillin-streptomycin, and filter with a $0.2-\mu \mathrm{m}$ filter under aseptic conditions. Keep sterile and store up to 1 month at $4^{\circ} \mathrm{C}$.

\section{Phosphate-buffered saline (PBS)}

Dissolve $8 \mathrm{~g} \mathrm{NaCl}, 0.2 \mathrm{~g} \mathrm{KCl}, 0.61 \mathrm{~g} \mathrm{Na}_{2} \mathrm{HPO}_{4}$, and $0.2 \mathrm{~g} \mathrm{KH}_{2} \mathrm{PO}_{4}$ in $900 \mathrm{ml}$ MilliQ-purified water. Adjust $\mathrm{pH}$ to 7.4 using $\mathrm{HCl}$ or $\mathrm{NaOH}$ and bring the solution to a final volume of 1 liter with MilliQ-purified water. Autoclave the solution. Store this solution up to 1 year at room temperature and always shake before use.

\section{Resazurin stock solution, $1 \mathrm{mg} / \mathrm{ml}$}

Dissolve $1 \mathrm{mg}$ of resazurin in $1 \mathrm{ml}$ in sterile PBS (see recipe). Filter the solution using a $0.2-\mu \mathrm{m}$ filter, protect the solution from light with aluminum foil, and keep frozen up to 1 month at $-20^{\circ} \mathrm{C}$. On the day of the assay, defrost the resazurin solution in a $37^{\circ} \mathrm{C}$ water bath, and further dilute the $1: 1000$ solution in growth medium (see recipe) under aseptic conditions.

\section{SRB solution, $0.05 \%(w / v)$}

Dissolve $0.25 \mathrm{~g}$ of sulforhodamine B (SRB; Sigma, cat no. S9012) in $500 \mathrm{ml}$ of of $1 \%(\mathrm{v} / \mathrm{v})$ acetic acid in MilliQ-purified water, and keep protected from light with aluminum foil. Store this solution up to 1 year at $4^{\circ} \mathrm{C}$. 
Tris-NaOH, $10 \mathrm{mM}, \mathrm{pH} 10$

Dissolve $0.64 \mathrm{~g}$ of Tris base in $400 \mathrm{ml}$ of MilliQ-purified water. Adjust $\mathrm{pH}$ to 10.5 with $1 \mathrm{M} \mathrm{NaOH}$ and bring the solution to a final volume of $500 \mathrm{ml}$ with MilliQ-purified water. Store this solution up to 1 year at room temperature.

\section{COMMENTARY}

\section{Background Information}

Decreasing the cost of developing new compounds and improving their time to market are two great challenges for pharmaceutical industry (Adams and Brantner, 2006; Taylor, 2015). Pre-clinical tests that can predict drug behavior in humans before reaching clinical assays are the standard approach in drug-development pipelines (Brodniewicz and Grynkiewicz, 2010). Cell viability assays that simultaneously measure the cell mass and metabolic activity in the same sample of cells may be considered important tools to predict human toxicity and to detect toxic thresholds of different types of chemicals. Here we describe a cell viability method that can measure cell mass and metabolic activity using a tandem resazurin/SRB assay in skin BJ fibroblasts.

The resazurin reduction test (also known as Alamar Blue assay) was developed in

the 1950 s to assess bacterial or yeast contamination in biological fluids and milk (Erb and Ehlers, 1950). It still has current widespread use in measuring the metabolic activity of mammalian cells (Fields and Lancaster, 1993). In this assay, viable cells with active metabolism reduce resazurin (nonfluorescent dye, blue) to resorufin (pink fluorescent dye; see Fig. 2.24.2), with fluorescence output being proportional to the number of metabolically active and viable cells (O'Brien et al., 2000; Abdoli et al., 2015). The principal advantages of this assay are simplicity, versatility, reproducibility, sensitivity, and low cost (Voytik-Harbin et al., 1998), as well as the fact that it does not involve cell lysis and can be performed with other tests or kinetic measurements on the same set of cells (Zumpe et al., 2010). The main disadvantages of this method are possible fluorescent interference of

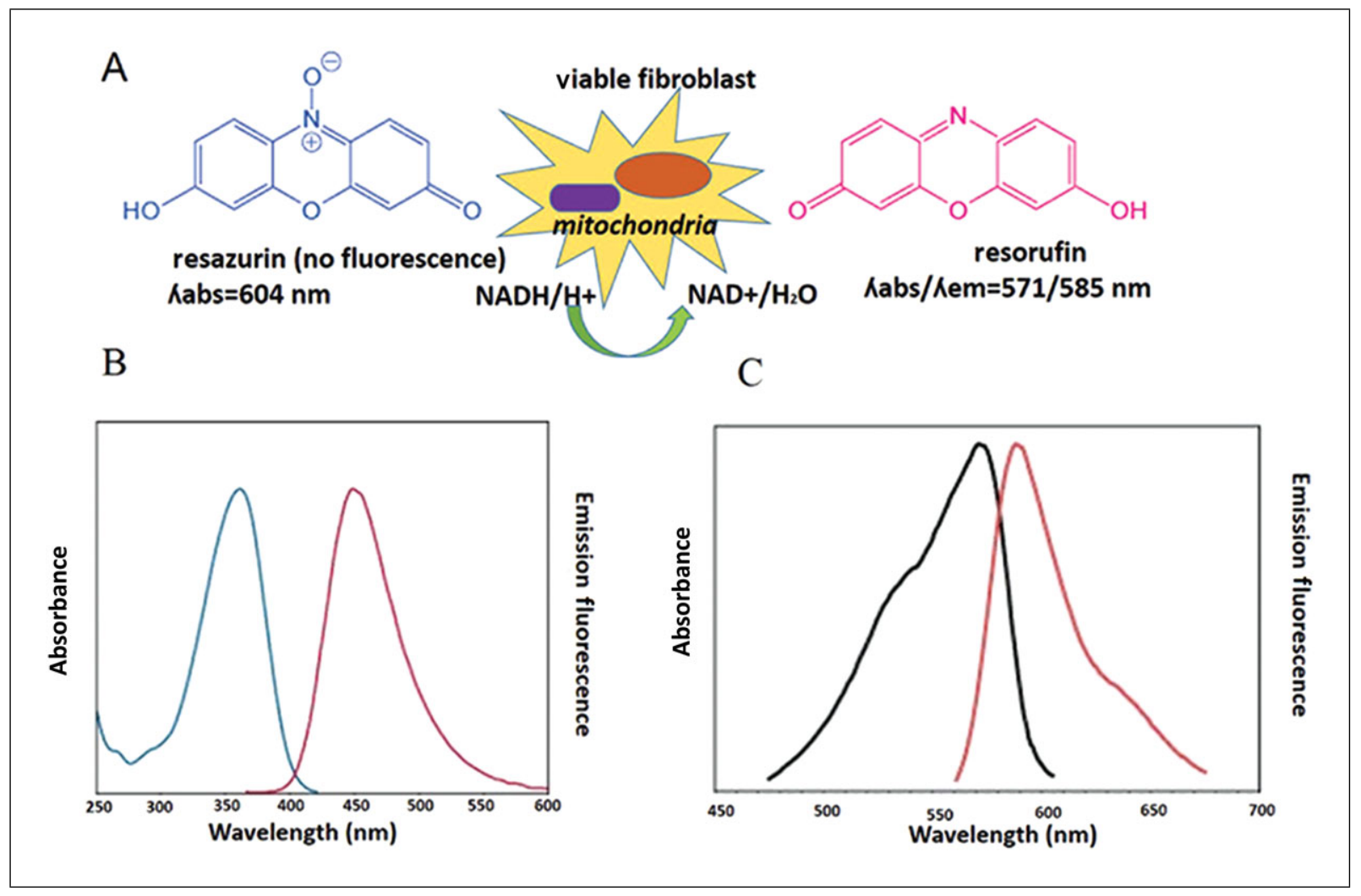

Figure 2.24.2 Reduction of resazurin and formation of resorufin product. Resazurin, a non-fluorescent dye with blue color, is converted a resorufin, a pink fluorescent product $(\mathbf{A})$. Spectrum of absorbance and emission of resazurin (B) and resorufin (C), obtained online from http://www.uniscience.com/analises-de-viabilidade-e-citotoxidade/resazurincell-viability-assay-kit-biotium, accessed November 2015. 
Table 2.24.1 Critical Parameters and Troubleshooting Guide for Determining Cell Viability Using a Tandem Resazurin/Sulforhodamine B Assay

\begin{tabular}{|c|c|c|}
\hline Problem found & Possible cause & Solution \\
\hline \multirow[t]{3}{*}{$\begin{array}{l}\text { Low fluorescence } \\
\text { signal detected by } \\
\text { resazurin assay }\end{array}$} & $\begin{array}{l}\text { Low cell density and/or short } \\
\text { incubation time with } \\
\text { resazurin }\end{array}$ & $\begin{array}{l}\text { Try different cells densities and perform a time course for } \\
\text { resorufin formation. Make sure that the cell density and the } \\
\text { incubation time with resazurin used are optimal. }\end{array}$ \\
\hline & $\begin{array}{l}\text { Inadequate preparation of } \\
\text { resazurin solution }\end{array}$ & $\begin{array}{l}\text { Ensure that the working resazurin solution is prepared on } \\
\text { the day of the experiment by dilution of the stock solution } \\
\text { of resazurin and kept protected from light with aluminum } \\
\text { foil. Renew the stock solution of resazurin after } 10-20 \\
\text { freeze/thaw cycles. }\end{array}$ \\
\hline & $\begin{array}{l}\text { Failure to protect plate } \\
\text { incubated with resazurin from } \\
\text { light }\end{array}$ & $\begin{array}{l}\text { Verify that the plate is well covered with aluminum foil } \\
\text { after adding the working resazurin solution }\end{array}$ \\
\hline \multirow[t]{3}{*}{$\begin{array}{l}\text { Low reproducibility } \\
\text { of } \mathrm{SRB} \text { assay }\end{array}$} & $\begin{array}{l}\text { Inefficient removal of excess } \\
\text { SRB on the plate after } \\
\text { incubation }\end{array}$ & $\begin{array}{l}\text { Ensure that the excess of SRB is completely removed in the } \\
\text { washing step. The acetic acid wash solution should come } \\
\text { out clear from the plate. }\end{array}$ \\
\hline & Inefficient fixation of cells & $\begin{array}{l}\text { Ensure that the solution of } 1 \% \text { acetic acid in MilliQ-purified } \\
\text { water is added slowly to the plate; otherwise, cell } \\
\text { detachment may occur }\end{array}$ \\
\hline & $\begin{array}{l}\text { Cell loss during the washing } \\
\text { steps }\end{array}$ & $\begin{array}{l}\text { Ensure gentle aspiration of medium or PBS; make sure not } \\
\text { to touch the monolayer cells with the pipet tips, and ensure } \\
\text { that the vacuum force is not too strong }\end{array}$ \\
\hline \multirow[t]{2}{*}{$\begin{array}{l}\text { Low correlation } \\
\text { between SRB and } \\
\text { resazurin assays }\end{array}$} & $\begin{array}{l}\text { Poor optimization of } \\
\text { resazurin and SRB assays for } \\
\text { the cell lines in study }\end{array}$ & Check the previous comments \\
\hline & Fluorescence interference & $\begin{array}{l}\text { Determination of the fluorescence signal of samples with } \\
\text { test compound without resazurin }\end{array}$ \\
\hline
\end{tabular}

tested compounds, and intrinsic toxicity of resazurin for particular cell types (Riss et al., 2004), although this can be easily assessed by performing proper controls with alternative viability assays.

The sulforhodamine B assay is another technique currently used for measuring cell mass, which was established by Skehan et al. (1990) and subsequently adopted for routine use in the National Cancer Institute in vitro antitumor screen (Kerkvliet, 1990; Abdoli et al., 2015). This assay infers cell growth by direct quantification of total protein mass, not relying on the direct determination of the metabolic function or activity of living cells (Papazisis et al., 1997), thus eliminating the influence of varying biological parameters such as increased metabolic rate or variations in mitochondrial activity. This assay is based on binding of the SRB dye to basic amino acids in cellular proteins, with a colorimetric evaluation providing an estimate of total cellular protein, which is related to cell number (Papazisis et al., 1997). The advantages of the SRB assay include the lower cost, good linearity, higher sensitivity, and stable endpoint (Papazisis et al., 1997). Therefore, the tandem combination of these two assays would allow evaluation of metabolic activity of a known cell population, which is calculated from its mass, resulting in a more confident prediction of the human toxicity and detection of toxic thresholds for the tested compounds.

\section{Critical Parameters and Troubleshooting}

Critical Parameters and Troubleshooting are summarized in Table 2.24.1.

\section{Anticipated Results}

The results of the study shown here provide insights for optimization of a dual resazurin/sulforhodamine B assay, which can easily be used in different cell lines. This is an innovative, simple, highly reproducible, and informative cell viability assay that measures cell mass and metabolic activity in the same cell sample, eliminating the variation associated with cell seeding and also minimizing time and costs associated with conducting separate assays for individual cell samples. 


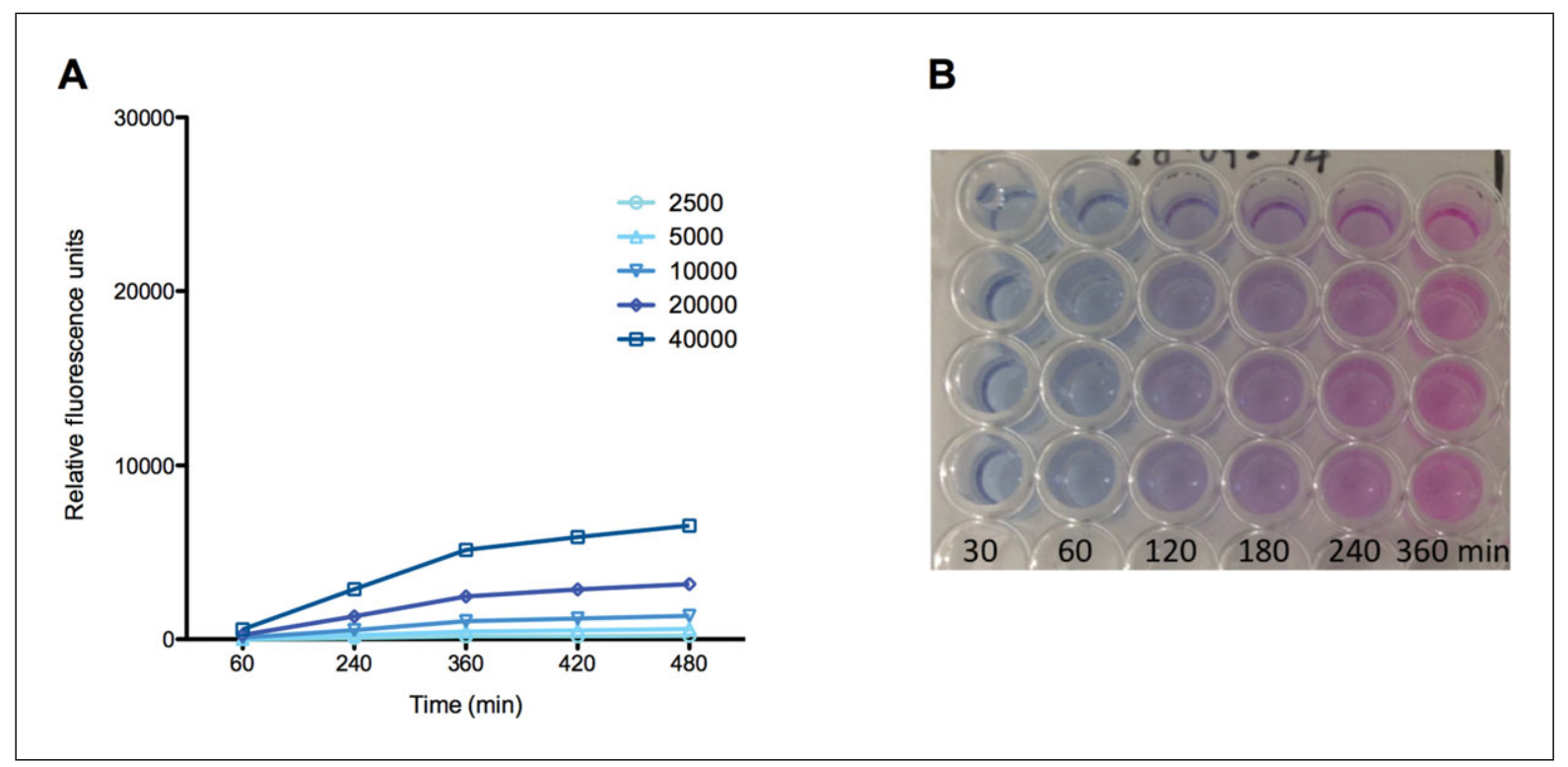

Figure 2.24.3 Validation of the optimal time for measuring the metabolic activity of skin BJ fibroblasts by resazurin assay. BJ skin fibroblast cells seeded at different densities $\left(0.25,0.5,1,2\right.$, and $4 \times 10^{4}$ cells $\left./ \mathrm{cm}^{2}\right)$ in DMEM medium were kept in culture during $24 \mathrm{hr}$ and then incubated with resazurin for $1,4,6,7$, and $8 \mathrm{hr}$. The metabolic activity was determined by resorufin fluorescence measurement using $450 \mathrm{~nm}$ excitation/490 nm emission, and expressed in relative fluorescence units. The values are expressed as mean \pm SEM (standard error of the mean) of five independent experiments (when the error bars are not visible, SEM is hidden by the size of the symbols) (A). Colorimetric alteration of resazurin during incubation with cells during 30,60, 120, 180, 240 and 360 min (B).

In the optimization process for the dual resazurin/sulforhodamine B assay, it is imperative to first determine the optimal incubation time with resazurin that is required to measure cellular metabolic activity, since this factor largely influences the sensitivity of this assay. Selection of the incubation period should take into account the smallest possible time of incubation required to reflect a practical conversion of all resazurin, and, whenever possible, the time that most accurately reflects the differences in the cell densities used. One example is shown in Figure 2.24.3, where skin BJ fibroblasts seeded at different densities $(0.25$, $0.5,1,2$, and $4 \times 10^{4}$ cells $/ \mathrm{cm}^{2}$ ) and different culture times $(24,48,72,96,120,144,168$, and $192 \mathrm{hr}$ ) present an optimal incubation time with resazurin of $6 \mathrm{hr}$. In this case, it is clear that $6 \mathrm{hr}$ is the minimal time of incubation that reflects a practical conversion of all resazurin. In fact, increasing the time of incubation with resazurin up to $8 \mathrm{hr}$ does not improve the resolution of the fluorescence signal in detecting different cell densities (Figs. 2.24.3 and 2.24.4).

It should be noted, however, that the optimal time of incubation with resazurin changes mainly with the metabolic activity of cells and cell density used. It is thus expected that cells with higher metabolic activity require a shorter time of incubation with resazurin, while cells with lower metabolic activity may require a longer time of incubation with resazurin. Accordingly, some examples of different cell lines used in our laboratory with different incubation times with resazurin are shown in Table 2.24.2, which may be a helpful tool to predict the range of incubation times for a given cell line.

After choosing the optimal incubation time with resazurin, one should proceed to the analysis of metabolic activity and cell mass separately along the time of cell culture (for the optimal time of incubation with resazurin). Figures 2.24.5 and 2.24.6 demonstrate the variation of metabolic activity and cell mass of skin BJ fibroblasts along different culture times, incubating with resazurin for $6 \mathrm{hr}$.

The final step is to establish a correlation between metabolic activity and cell mass, since this parameter provides a reliable determination of cell viability. As observed in Figure 2.24.7, this allows accurate determination of whether metabolic activity is directly proportional to cell density. However, it should be noted that analysis of this parameter can confirm that the resultant fluorescent signal is an accurate reflection of cellular metabolic activity devoid of any interference from factors such as resazurin toxicity or fluorescent quenching.
Assessment of Cell Toxicity

2.24.9

Supplement 68 


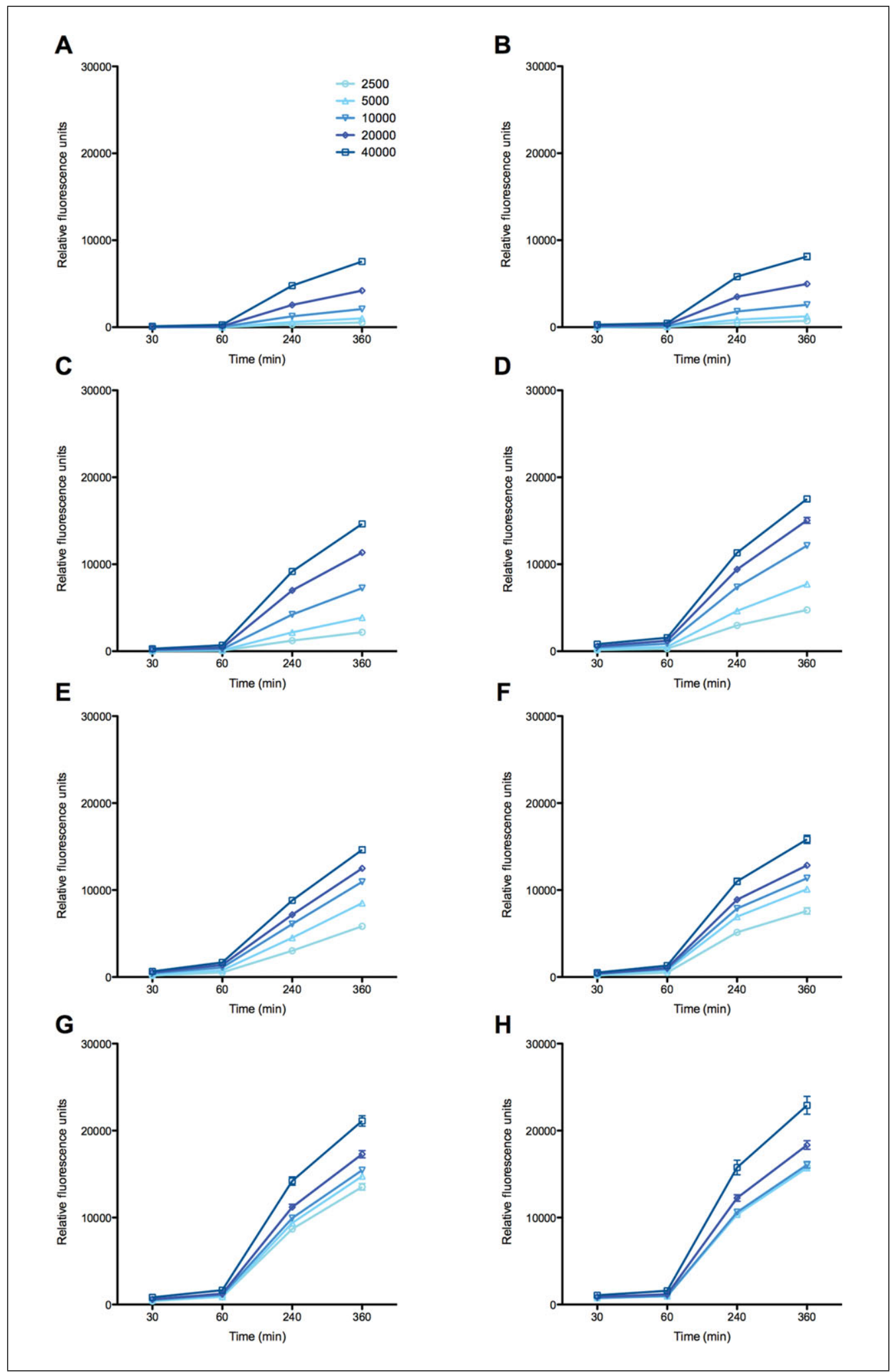

Figure 2.24.4 Metabolic activity of skin BJ fibroblasts along different times of incubation with resazurin. Skin BJ fibroblast cells seeded in DMEM medium at different densities $(0.25,0.5,1,2$, and $4 \times 10^{4}$ cells $/ \mathrm{cm}^{2}$ ) were kept in culture during $24(\mathbf{A}), 48(\mathbf{B}), 72(\mathbf{C}), 96(\mathbf{D}), 120$ (E), 144 (F), $168(\mathbf{G})$, and $192 \mathrm{hr}(\mathbf{H})$, and then incubated with resazurin for $30,60,240$, and $360 \mathrm{~min}$. Metabolic activity was determined by resorufin fluorescence measurement using $450 \mathrm{~nm}$ excitation/490 nm emission, and expressed in relative fluorescence units. Each point represents the mean \pm SEM

SRB/Resazurin Assay for Cell Viability and Metabolism (standard error of the mean) of four independent experiments (when the error bars are not visible, SEM is hidden by the size of the symbols). 
Table 2.24.2 Optimal Times of Incubation with Resazurin of Different Cell Lines Used in Our Laboratory

\begin{tabular}{|c|c|c|c|c|c|c|c|c|c|}
\hline Cell line & $\begin{array}{l}\text { Product } \\
\text { number }\end{array}$ & Organism & Tissue & Cell type & $\begin{array}{l}\text { Cell } \\
\text { amount } \\
\left(\text { cells } / \mathrm{cm}^{2}\right)\end{array}$ & Plate & $\begin{array}{l}\text { Resazurin } \\
\text { concentration }\end{array}$ & $\begin{array}{l}\text { Volume } \\
(\mu 1)\end{array}$ & $\begin{array}{l}\text { Recom- } \\
\text { mended } \\
\text { time (hr) }\end{array}$ \\
\hline$\overline{\mathrm{BJ}}$ & $\begin{array}{l}\text { ATCC } \\
\text { CRL-2522 }\end{array}$ & $\begin{array}{l}\text { Homo } \\
\text { sapiens }\end{array}$ & $\begin{array}{l}\text { Skin/ } \\
\text { foreskin }\end{array}$ & $\begin{array}{l}\text { Normal } \\
\text { fibroblast }\end{array}$ & 40,000 & 48 well & $1 \mu \mathrm{g} / \mathrm{ml}$ & 500 & 6 \\
\hline A549 & $\begin{array}{l}\text { ATCC } \\
\text { CCL-185 }\end{array}$ & $\begin{array}{l}\text { Homo } \\
\text { sapiens }\end{array}$ & Lung & $\begin{array}{l}\text { Epithelial } \\
\text { carcinoma }\end{array}$ & 25,500 & 48 well & $10 \mu \mathrm{g} / \mathrm{ml}$ & 500 & 1 \\
\hline MRC5 & $\begin{array}{l}\text { ATCC } \\
\text { CCL-171 }\end{array}$ & $\begin{array}{l}\text { Homo } \\
\text { sapiens }\end{array}$ & Lung & $\begin{array}{l}\text { Normal } \\
\text { fibroblast }\end{array}$ & 12,500 & 48 well & $10 \mu \mathrm{g} / \mathrm{ml}$ & 500 & 1 \\
\hline HEPG2 & $\begin{array}{l}\text { ATCC } \\
\text { HB-8065 }\end{array}$ & $\begin{array}{l}\text { Homo } \\
\text { sapiens }\end{array}$ & Liver & $\begin{array}{l}\text { Hepatocyte } \\
\text { carcinoma }\end{array}$ & 60,000 & 96 well & $10 \mu \mathrm{g} / \mathrm{ml}$ & 80 & 0.5 \\
\hline H9C2 & $\begin{array}{l}\text { ATCC } \\
\text { CRL-1446 }\end{array}$ & $\begin{array}{l}\text { Rattus } \\
\text { norvegicus }\end{array}$ & $\begin{array}{l}\text { Heart/ } \\
\text { myocardium }\end{array}$ & Myoblast & 10,500 & 96 well & $10 \mu \mathrm{g} / \mathrm{ml}$ & 80 & 0.5 \\
\hline MLO-A5 ${ }^{a}$ & $-^{b}$ & $\begin{array}{l}\text { Mus } \\
\text { musculus }\end{array}$ & Bone & $\begin{array}{l}\text { Late } \\
\text { osteoblasts }\end{array}$ & 5,000 & 24 well & $10 \mu \mathrm{g} / \mathrm{ml}$ & 1000 & 8 \\
\hline MLO-Y4 ${ }^{c}$ & $\square^{b}$ & $\begin{array}{l}\text { Mus } \\
\text { musculus }\end{array}$ & Bone & Osteocytes & 15,000 & 24 well & $10 \mu \mathrm{g} / \mathrm{ml}$ & 1000 & $8-16$ \\
\hline
\end{tabular}

${ }^{a}$ Kato et al. (2001).

${ }^{b}$ No commercial availability.

${ }^{c}$ Kato et al. (1997).

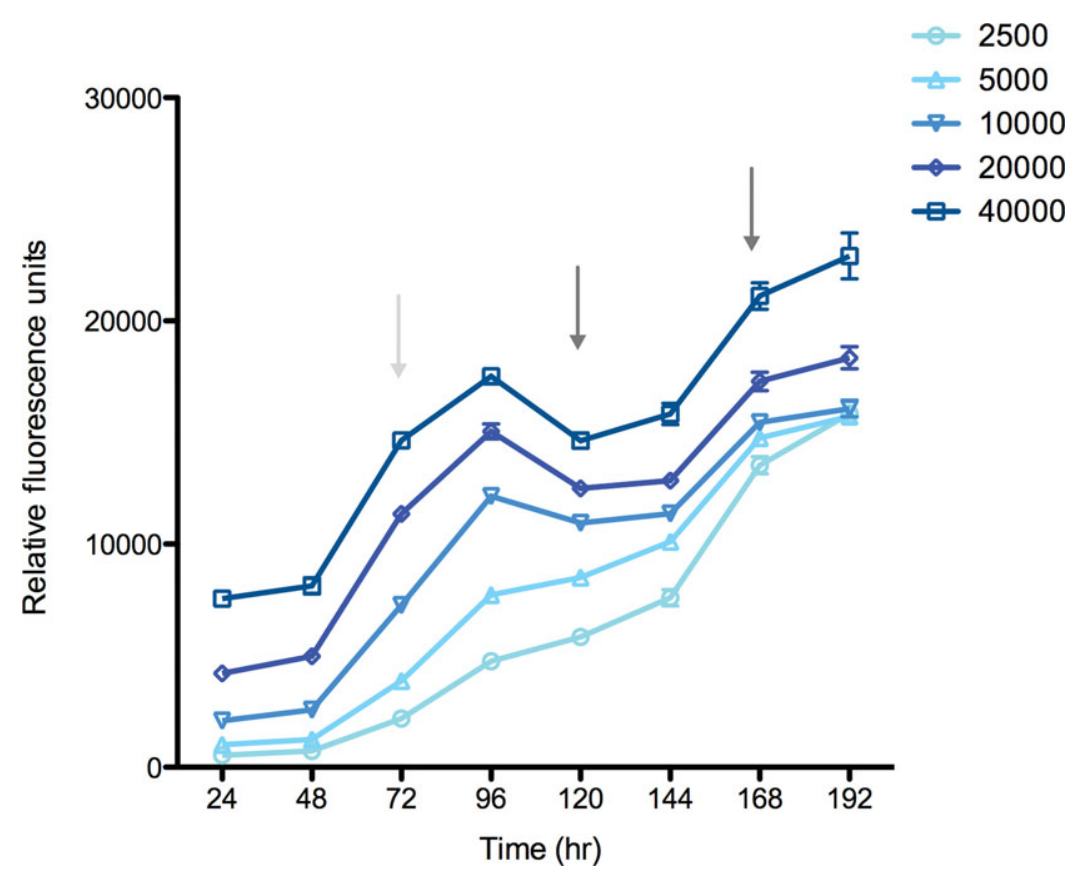

Figure 2.24.5 Metabolic activity of skin BJ fibroblasts along different culture times, measured by the resazurin assay. Skin BJ fibroblasts seeded at different densities $(0.25,0.5,1$, 2 , and 4 $\times 10^{4}$ cells $/ \mathrm{cm}^{2}$ ) in DMEM medium were kept in culture during $24,48,72,96,120,144,168$, and $192 \mathrm{hr}$, and then incubated with resazurin for $6 \mathrm{hr}$. Metabolic activity was determined by resorufin fluorescence measurement using $450 \mathrm{~nm}$ excitation/490 nm emission, and expressed in relative fluorescence units. The arrows correspond to time points when replacement of cell culture medium occurred. The values are expressed as mean \pm SEM (standard error of the mean) of four independent experiments (when the error bars are not visible, SEM is hidden by the size of the symbols).

Assessment of Cell Toxicity

\subsubsection{1}

Supplement 68 


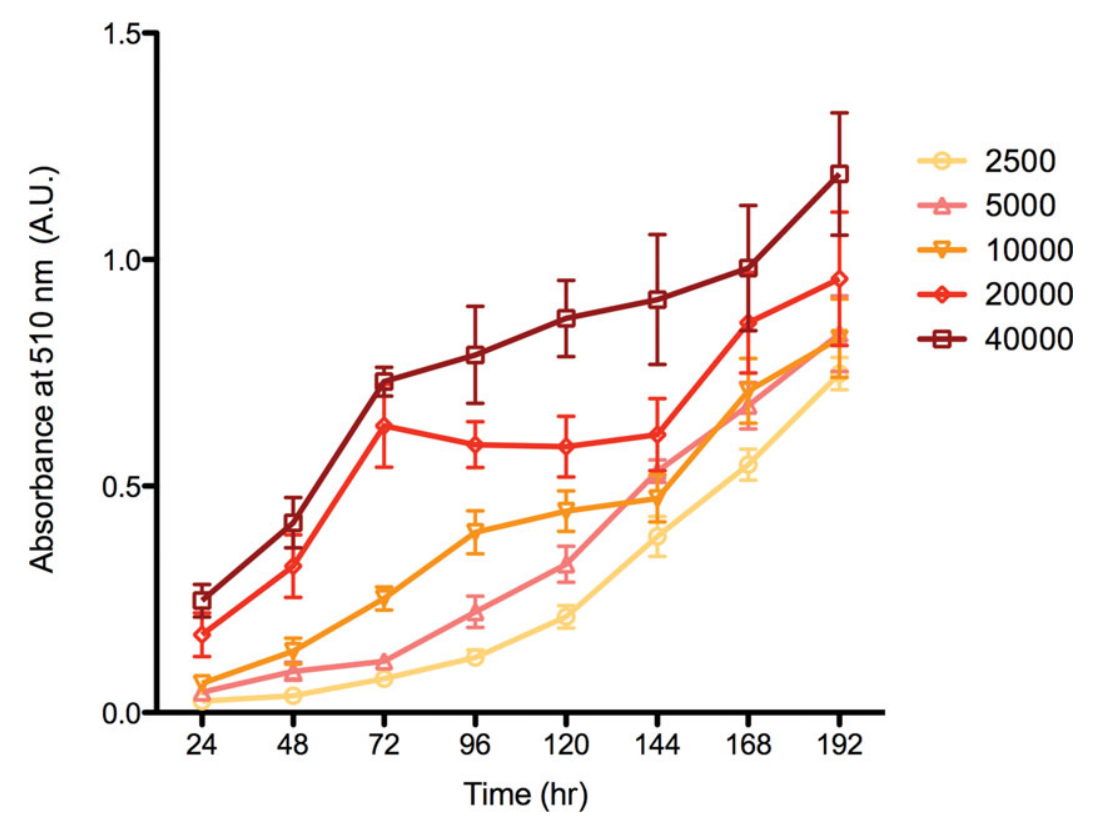

Figure 2.24.6 BJ fibroblasts mass along different times in culture, as measured by the sulforhodamine B assay. Skin BJ fibroblasts seeded at different densities $\left(0.25,0.5,1,2\right.$, and $4 \times 10^{4}$ cells $/ \mathrm{cm}^{2}$ ) in DMEM medium were kept in culture during 24, 48, 72, 96, 120, 144, 168, and $192 \mathrm{hr}$. Cell mass was determined by the measurement of optical density at $510 \mathrm{~nm}$ wavelength against background measured at $620 \mathrm{~nm}$. Each point represents the mean \pm SEM (standard error of the mean) of four independent experiments (when the error bars are not visible, SEM is hidden by the size of the symbols).

SRB/Resazurin Assay for Cell Viability and Metabolism

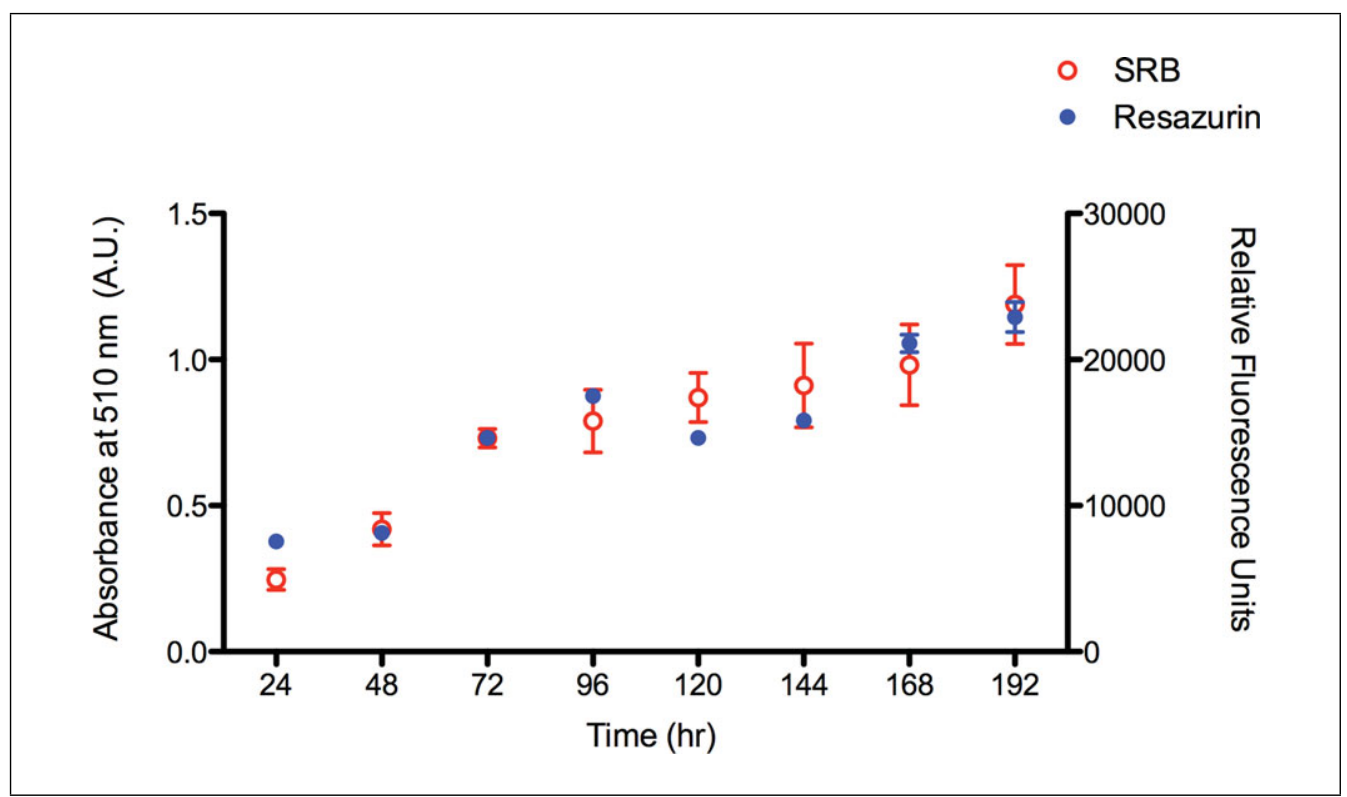

Figure 2.24.7 Correlation between cell mass and metabolic activity of skin BJ fibroblasts along different culture times. Skin BJ fibroblasts cells seeded at $4 \times 10^{4}$ cells $/ \mathrm{cm}^{2}$ in DMEM medium were kept in culture during 24, 48, 72, 96, 120, 144, 168 and $192 \mathrm{hr}$. Cell mass was determined by measuring optical density at $510 \mathrm{~nm}$ against $620 \mathrm{~nm}$ background, and metabolic activity determined by resorufin fluorescence measurement at $6 \mathrm{hr}$ using $450 \mathrm{~nm}$ excitation/490 nm emission wavelength, and expressed in relative fluorescence units. The values are represented as mean \pm SEM (standard error of the mean) of four independent experiments (when the error bars are not visible, SEM is hidden by the size of the symbols). 


\section{Time Considerations}

\section{Basic Protocol 1}

Medium preparation, $\sim 1 \mathrm{hr}$

BJ fibroblast growth in culture prior to study, $\sim 2$ weeks

Cell passage, $30 \mathrm{~min}$

Cell seeding, $\sim 60 \mathrm{~min}$

Cell growth in 48-well plates, up to $192 \mathrm{hr}$.

\section{Basic Protocol 2}

$1 \mathrm{mg} / \mathrm{ml}$ stock solution of resazurin (no time limitation), $\sim 20$ to $30 \mathrm{~min}$

Preparation of resazurin solution on the day of assay by dilution of stock solution, $\sim 15$ to $20 \mathrm{~min}$

Time of incubation with resazurin, up to $8 \mathrm{hr}$

Fluorescence reading $\sim 5$ min each time.

\section{Basic Protocol 3}

Preparation SRB solution (no time limitation), $30 \mathrm{~min}$

Fixation step, at least $3 \mathrm{hr}$

Drying plate and incubation with SRB, $\sim 2 \mathrm{hr}$

Drying plate and dissolution in Tris- $\mathrm{NaOH}$, $1 \mathrm{hr}, 30 \mathrm{~min}$

Transfer to 96-well plate and read absorbance. $\sim 15 \mathrm{~min}$.

\section{Acknowledgments}

The work presented was funded by Fundação Montepio under the project "An Epigenetic Engineering Approach to Reverse the Parkinson Disease Cell State (PD-state)." This investigation also used resources supported by FEDER funds through the Operational Programme Competitiveness Factors (COMPETE) and national funds by FCT (Foundation for Science and Technology) under a Ph.D. fellowship addressed to S.P.P. (SFRH/BD/64694/2009), strategic projects UID/NEU/04539/2013, and QREN project \#4832 "Stemcell based platforms for Regenerative and Therapeutic Medicine" with reference CENTRO-07-ST24-FEDER-002008" funded through FEDER/QREN 2007-2013. I.G.S., V.V.I., and A.A.R. were supported by the Russian Government Program of Competitive Growth of Kazan Federal University and subsidy allocated to Kazan Federal University for state assignment in the sphere of scientific activities.

The funding agencies had no role in study design, data collection and analysis, decision to publish, or preparation of this document.
Literature Cited

Abdoli, N., Azarmi, Y., and Eghbal, M.A. 2015. Mitigation of statins-induced cytotoxicity and mitochondrial dysfunction by L-carnitine in freshly-isolated rat hepatocytes. Res. Pharm. Sci. 10:143-151.

Adams, C.P. and Brantner, V.V. 2006. Estimating the cost of new drug development: Is it really 802 million dollars? Health Aff. 25:420-428. doi: 10.1377/hlthaff.25.2.420.

Ahmed, S.A., Gogal, R.M., Jr., and Walsh, J.E. 1994. A new rapid and simple nonradioactive assay to monitor and determine the proliferation of lymphocytes: An alternative to $[3 \mathrm{H}]$ thymidine incorporation assay. J. Immunol. Methods 170:211-224. doi: 10.1016/0022-1759(94)90396-4.

Allen, D.D., Caviedes, R., Cardenas, A.M., Shimahara, T., Segura-Aguilar, J., and Caviedes, P.A. 2005. Cell lines as in vitro models for drug screening and toxicity studies. Drug Dev. Ind. Pharm. 31:757-768. doi: 10.1080/03639040500216246.

Ambrosi, G., Ghezzi, C., Sepe, S., Milanese, C., Payan-Gomez, C., Bombardieri, C.R., Armentero, M.T., Zangaglia, R., Pacchetti, C., Mastroberardino, P.G., and Blandini, F. 2014. Bioenergetic and proteolytic defects in fibroblasts from patients with sporadic Parkinson's disease. Biochim. Biophys. Acta 1842:13851394. doi: 10.1016/j.bbadis.2014.05.008.

Bopp, S.K. and Lettieri, T. 2008. Comparison of four different colorimetric and fluorometric cytotoxicity assays in a zebrafish liver cell line. BMC Pharmacol. 8:8. doi: 10.1186/1471-2210-8-8.

Brodniewicz, T. and Grynkiewicz, G. 2010. Preclinical drug development. Acta Pol. Pharm. 67:578-585.

Connolly, G.P. 1998. Fibroblast models of neurological disorders: Fluorescence measurement studies. Trends Pharmacol. Sci. 19:171-177. doi: 10.1016/S0165-6147(98)01202-4.

de Fries, R. and Mitsuhashi, M. 1995. Quantification of mitogen induced human lymphocyte proliferation: Comparison of alamarBlue assay to ${ }^{3} \mathrm{H}$-thymidine incorporation assay. J. Clin. Lab. Anal. 9:89-95. doi: 10.1002/jcla.1860090203.

Erb, R.E. and Ehlers, M.H. 1950. Resazurin reducing time as an indicator of bovine semen capacity. J. Dairy Sci. 33:853-864. doi: 10.3168/jds.S0022-0302(50)91981-3.

Fairbanks, L.D., Jacomelli, G., Micheli, V., Slade, T., and Simmonds, H.A. 2002. Severe pyridine nucleotide depletion in fibroblasts from LeschNyhan patients. Biochem. J. 366:265-272. doi: 10.1042/bj20020148.

Fields, R.D. and Lancaster, M.V. 1993. Dualattribute continuous monitoring of cell proliferation/cytotoxicity. Am. Biotechnol. Lab. 11:4850.

Garrido-Maraver, J., Cordero, M.D., Monino, I.D., Pereira-Arenas, S., Lechuga-Vieco, A.V., Cotan, D., De la Mata, M., Oropesa-Avila, M., De
Assessment of Cell Toxicity

2.24 .13

Supplement 68 
Miguel, M., Bautista Lorite, J., Rivas Infante, E., Alvarez-Dolado, M., Navas, P., Jackson, S., Francisci, S., and Sanchez-Alcazar, J.A. 2012. Screening of effective pharmacological treatments for MELAS syndrome using yeasts, fibroblasts and cybrid models of the disease. Br. J. Pharmacol. 167:1311-1328. doi: 10.1111/j.1476-5381.2012.02086.x.

Kato, Y., Windle, J.J., Koop, B.A., Mundy, G.R., and Bonewald, L.F. 1997. Establishment of an osteocyte-like cell line, MLO-Y4. J. Bone Miner. Res. 12:2014-2023.

Kato, Y., Boskey, A., Spevak, L., Dallas, M., Hori, M., and Bonewald, L.F. 2001. Establishment of an osteoid preosteocyte-like cell MLO-A5 that spontaneously mineralizes in culture. J. Bone Miner. Res. 16:1622-1633.

Kerkvliet, G.J. 1990. Drug discovery screen adapts to changes. J. Natl. Cancer Inst. 82:1087-1088. doi: 10.1093/jnci/82.13.1087.

Lee, J.K., Kim, D.B., Kim, J.I., and Kim, P.Y. 2000. In vitro cytotoxicity tests on cultured human skin fibroblasts to predict skin irritation potential of surfactants. Toxicol. In Vitro 14:345-349. doi: 10.1016/S0887-2333(00)00028-X.

Mocali, A., Della Malva, N., Abete, C., Mitidieri Costanza, V.A., Bavazzano, A., Boddi, V., Sanchez, L., Dessi, S., Pani, A., and Paoletti, F. 2014. Altered proteolysis in fibroblasts of Alzheimer patients with predictive implications for subjects at risk of disease. Int. J. Alzheimer's Dis. 2014:520152. doi: 10.1155/2014/520152.

Moreira, A.C., Branco, A.F., Sampaio, S.F., Cunha-Oliveira, T., Martins, T.R., Holy, J., Oliveira, P.J., and Sardao, V.A. 2014. Mitochondrial apoptosis-inducing factor is involved in doxorubicin-induced toxicity on H9c2 cardiomyoblasts. Biochim. Biophys. Acta 1842:2468-2478. doi: 10.1016/j.bbadis.2014. 09.015 .

Nguyen, K.V. 2014. Epigenetic regulation in amyloid precursor protein and the Lesch-Nyhan syndrome. Biochem. Biophys. Res. Commun. 446:1091-1095. doi: 10.1016/j.bbrc.2014.03. 062.

Niles, A.L., Moravec, R.A., and Riss, T.L. 2008. Update on in vitro cytotoxicity assays for drug development. Expert Opin. Drug Discov. 3:655669. doi: 10.1517/17460441.3.6.655.

O'Brien, J., Wilson, I., Orton, T., and Pognan, F. 2000. Investigation of the Alamar Blue (resazurin) fluorescent dye for the assessment of mammalian cell cytotoxicity. Eur. J. Biochem. 267:5421-5426. doi: 10.1046/j.1432-1327. 2000.01606.x.

Papazisis, K.T., Geromichalos, G.D., Dimitriadis, K.A., and Kortsaris, A.H. 1997. Optimization of the sulforhodamine B colorimetric assay. J. Immunol. Methods 208:151-158. doi: 10.1016/S0022-1759(97)00137-3.

Phelan, M.C. 2007. Techniques for mammalian cell tissue culture. Curr. Protoc. Toxicol. 33:A.3B.1A.3B.18, doi: 10.1002/0471140856.txa03bs33.
Riss, T.L., Moravec, R.A., Niles, A.L., Benink, H.A., Worzella, T.J., and Minor, L. 2004. Cell viability assays. In Assay Guidance Manual (G.S. Sittampalam, N.P. Coussens, H. Nelson, M. Arkin, D. Auld, C. Austin, B. Bejcek, M. Glicksman, J. Inglese, P.W. Iversen, Z. Li, J. McGee, O. McManus, L. Minor, A. Napper, J.M. Peltier, T. Riss, O.J. Trask, Jr., and J. Weidner, eds.). Eli Lilly \& Company and the National Center for Advancing Translational Sciences (U.S.), Bethesda, Maryland.

Sardao, V.A., Oliveira, P.J., Holy, J., Oliveira, C.R., and Wallace, K.B. 2009. Doxorubicininduced mitochondrial dysfunction is secondary to nuclear p53 activation in H9c2 cardiomyoblasts. Cancer Chemother. Pharmacol. 64:811827. doi: 10.1007/s00280-009-0932-x.

Serafim, T.L., Matos, J.A., Sardao, V.A., Pereira, G.C., Branco, A.F., Pereira, S.L., Parke, D., Perkins, E.L., Moreno, A.J., Holy, J., and Oliveira, P.J. 2008. Sanguinarine cytotoxicity on mouse melanoma K1735-M2 cells-Nuclear vs. mitochondrial effects. Biochem. Pharmacol. 76:1459-1475. doi: 10.1016/j.bcp.2008.07.013.

Serafim, T.L., Carvalho, F.S., Marques, M.P., Calheiros, R., Silva, T., Garrido, J., Milhazes, N., Borges, F., Roleira, F., Silva, E.T., Holy, J., and Oliveira, P.J. 2011. Lipophilic caffeic and ferulic acid derivatives presenting cytotoxicity against human breast cancer cells. Chem. Res. Toxicol. 24:763-774. doi: 10.1021/tx200126r.

Skehan, P., Storeng, R., Scudiero, D., Monks, A., McMahon, J., Vistica, D., Warren, J.T., Bokesch, H., Kenney, S., and Boyd, M.R. 1990. New colorimetric cytotoxicity assay for anticancer-drug screening. J. Natl. Cancer Inst. 82:1107-1112. doi: 10.1093/jnci/82.13.1107.

Spryszynska, S., Smok-Pieniazek, A., Ferlinska, M., Roszak, J., Nocun, M., and Stepnik, M. 2015. The influence of ATM, ATR, DNA-PK inhibitors on the cytotoxic and genotoxic effects of dibenzo[def,p]chrysene on human hepatocellular cancer cell line HepG2. Mutat. Res. Genet. Toxicol. Environ. Mutagen. 791:12-24. doi: 10.1016/j.mrgentox.2015.07.008.

Taylor, D. 2015. The pharmaceutical industry and the future of drug development. In Pharmaceuticals in the Environment (R.E. Hester and R.M. Harrison, eds.) pp. 1-33. Royal Society of Chemistry Press, London.

Valente, A.X., das Neves, R.P., and Oliveira, P.J. 2012. Epigenetic engineering to reverse the Parkinson's expression state. Parkinsonism Relat. Disord. 18:717-721. doi: 10.1016/j.parkre ldis.2012.04.018.

Voytik-Harbin, S.L., Brightman, A.O., Waisner, B., Lamar, C.H., and Badylak, S.F. 1998. Application and evaluation of the alamarBlue assay for cell growth and survival of fibroblasts. In Vitro Cell. Dev. Biol. Anim. 34:239-246. doi: 10.1007/s11626-998-0130-x.

Wang, L., Ai, W., Zhai, Y., Li, H., Zhou, K., and Chen, H. 2015. Effects of Nano-CeO(2) with different nanocrystal morphologies on
Assay for Cell Viability and Metabolism 
cytotoxicity in HepG2 cells. Int. J. Environ. Res. Public Health 12:10806-10819. doi: 10.3390/ijerph120910806.

Yang, S., Zhang, K.Y., Kariawasam, R., Bax, M., Fifita, J.A., Ooi, L., Yerbury, J.J., Nicholson, G.A., and Blair, I.P. 2015. Evaluation of skin fibroblasts from amyotrophic lateral sclerosis patients for the rapid study of pathologi- cal features. Neurotoxic. Res. 28:138-146. doi: 10.1007/s12640-015-9532-1.

Zumpe, C., Bachmann, C.L., Metzger, A.U., and Wiedemann, N. 2010. Comparison of potency assays using different read-out systems and their suitability for quality control. J. Immunol. Methods 360:129-140. doi: 10.1016/j.jim.2010.06.019. 